1971. Of the $£ 1.8$ million current expenditure during the past year, $£ 0.9$ million was spent on research staff salaries, $£ 130,000$ on new equipment, and $£ 214,000$ on laboratory upkeep and materials.

\section{ICELANDIC SCIENCE}

\section{Need for Expansion}

ICELAND spends 0.39 per cent of its Gross National Product on research and development, a much smaller percentage than that in most other western countries, and the country's expenditure on research and development has only increased very slowly since 1950 when it ran at 0.17 per cent of the GNP (Reviews of National Science Policy, Iceland, OECD, Paris).

Research in Iceland is funded mostly by the government, which provides more than 70 per cent of the money, with industry running a poor second with 17 per cent of the research funding to its credit. In all, in 1971, 187.7 million Icelandic kroner ( $£ 79$ million) was spent on research and development which was allocated as follows: $\mathrm{Kr} 42.8$ million on basic and unspecified research, Kr41.6 million on argriculural research, Kr67.4 million on fisheries research, $\mathrm{Kr} 41.6$ million on agricultural and construction, $\mathrm{Kr} 24.3$ million on energy research and $\mathrm{Kr} 4.7$ million on medical research. In 1966 , by comparison, the total spent was $\mathrm{Kr} 72.7$ million and the greatest increase between 1966 and 1971 was in spending on fisheries research which went up from $\mathrm{Kr} 20.6$ million to $\mathrm{Kr} 67.4$ million.

The OECD examining team, consisting of Dr Alexander King, the Director General for Scientific Affairs at the OECD and Dr R. Major, the director of the Norwegian Council for Scientific and Industrial Research, has strong criticisms of the organization of research in Iceland. They say that the resources available for research are inadequate and that the absolute resources devoted to science "seems less than the critical amount necessary for a modern society".

Iceland has one university, and during 1970-71, 1,640 students were registered. But more than 700 Icelanders were studying abroad. Only 260 engineers and science students were registered at the University of Iceland in 1970-71 but a number of scientists were also studying abroad. Drs King and Major call for a further development of the Department of Technology and Science at the university which apart from redressing the balance of science students will form a nucleus for fundamental research "which should be oriented towards the specific natural conditions and national needs in Iceland". To overcome the difficulties of building up this department it is suggested that the staff of the Icelandic applied research institutes be involved in teaching in the university.

The National Research Council of Iceland was formed in 1940 and is the only body in the country charged with handling scientific matters on a broad basis. Iceland has no minister for science, and scientific affairs are dealt with separately by each ministry. The National Research Council is, at present, attached to the Ministry of Education but the examiners suggest that the council should be attached in future to the Prime Minister's office and also that it should be considerably strengthened by altering its membership with a view to making it a more active organization. The NRC, say the examiners, should take the initiative to create strategies and long-range plans for research activities "harmonized to the national goals of the country".

The examiners also suggest that the Icelandic applied science institutes should continue to report to their ministries but that they should strengthen their contacts with the users of their work and they also recommend that industry should be encouraged to undertake research projects. Very little research is undertaken in industry at present and this is "in the long run an unhealthy situation".

But the final words of advice from Dr King and Dr Major are that, apart from insufficient resources, the "main obstacle to the progress in science in Iceland appears to be the lack of communication and open dialogue".

\section{CIBA FOUNDATION}

\section{Fostering Relutions}

THE Ciba Foundation, which exists to promote international cooperation in medical and chemical research, spent $£ 160,000$ in 1972 and sponsored no fewer than thirteen symposia at its London headquarters in Portland Place, as well as holding several smaller meetings and discussions.

The foundation was set up in 1947 by CIBA Ltd and is now financed by that company's successor, CIBA-Geigy Ltd. Each year a third of the foundation's funds come from the parent company in Basle, a third from its subsidiary in Britain and a third from subsidiaries in the United States, Canada and Mexico among other countries.

Broadly speaking 50 per cent of the expenditure each year is for scientific purposes, 30 per cent for the maintenance of the "house"-in which, among other things, accommodation is provided free for scientists visiting Britain on business-and 20 per cent on administration. Although the lion's share of the scientific expenditure is on confer- ences and so on, the foundation does spend on average about $£ 1,200$ a year on its Anglo-French medical exchange bursaries, which allow young French and English scientists to interchange countries for a month or two. The foundation's annual report published recently lists nine bursaries-eight to British scientists-for 1972-73.

The Ciba Foundation also spends about $£ 500$ a year on associateships at the Royal Society of Medicine; this allows about twenty foreign students a year to make use of the facilities of the society without becoming full members.

Among the symposia held by the foundation in 1972 were ones on locomotion of tissue cells, corneal graft failures, and the medical care and protection of prisoners and other detainees.

\section{New job for Berrill?}

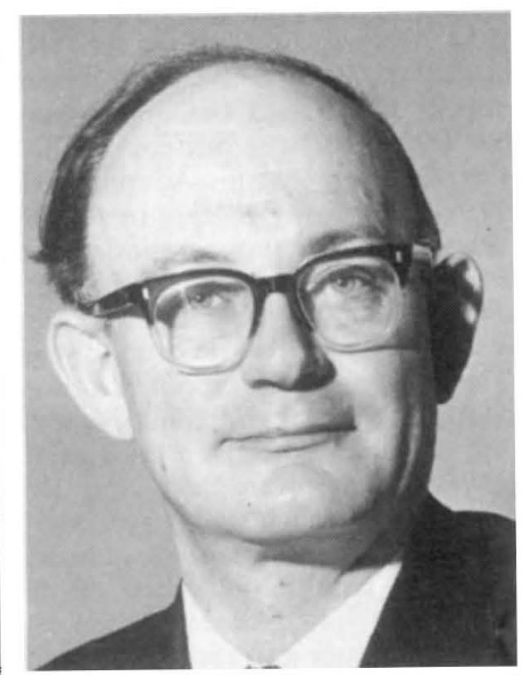

SIR KENNETH BERRILL, chairman of the University Grants Committee, is being tipped to become the government's Chief Economic Adviser later this year in succession to Sir Donald MacDougall. The Treasury was unable to confirm this week that his appointment is imminent, but Sir Kenneth, who is a product of the London School of Economics and Trinity College, Cambridge, and who was a lecturer in economics at Cambridge from 1949-69, has both experience as a government adviser and a reputation as an extremely able administrator.

Sir Kenneth became Chairman of the University Grants Committee in 1969 and is due to retire this year; from 1967-69 he was special adviser to the Treasury, and he has also been an economic adviser to Turkey, British Guiana and the OECD. 